\title{
Medvedev's Proposals for a New European Security Order: A Starting Point or the End of the Story?
}

\author{
Ulrich Kühn *
}

\section{Introduction}

On 29 November 2009, the Kremlin published the draft of a legally binding European security treaty on its website. ${ }^{1}$ The initiative launched by Russian President Dmitry Medvedev in 2008 for the rearrangement of Europe's security order thus reached its preliminary and unexpected climax, or perhaps an inconclusive endpoint. At their core, Medvedev's proposals aim at a codification of NATO's current borders, a recovery of Russian influence in the so-called "near abroad," and the establishment of legally binding "rules of the game" going forward in the realm of maintaining peace and stability in Europe.

Two factors of the Russian initiative are particularly salient. On the one hand, it repeats established Russian claims from the 1990s, often word-for-word; on the other, this hasty presentation of a sloppily drawn-up treaty has forced the West into a dialogue that, for all its desirability, risks becoming rapidly exhausted. All this is happening against the background of the aftermath of the Russian-Georgian war of 2008 and the offer made to Russia by the United States of a fresh start in their bilateral relations. The treaty's strange lack of substance coupled with its political unfeasibility makes it particularly hard to know what to do with the Russian initiative. Does the Kremlin simply want to reissue existing Russian demands, or could Medvedev's initiative be the starting point for a renewed dialogue about common security in Europe?

\section{Twenty Years After the Fall of the Berlin Wall: A Look Back}

A recent report by the EastWest Institute concluded that "the Euro-Atlantic security scene is characterized by a loss of mutual confidence, renewed tensions, and serious disagreements regarding not only practices but principles." ${ }^{2}$ With the Russian-Georgian war and the subsequent suspension of the NATO-Russia Council, the Cassandrastyle predictions of an imminent "New Cold War" seemed to be coming true. ${ }^{3}$ This negative development stands in stark contrast to the Charter of Paris for a New Europe,

\footnotetext{
Ulrich Kühn is a researcher and $\mathrm{PhD}$ student at the Institute for Peace Research and Security Policy at the University of Hamburg (IFSH) and a research assistant at the Helmut Schmidt University/University of the Federal Armed Forces Hamburg.

1 Available at http://eng.kremlin.ru/text/docs/2009/11/223072.shtml. Just a few days later, the Kremlin sent another draft treaty, this time only to members of the NATO-Russia Council. This document has still not been made public. The lack of availability limits the scope of this article to an assessment solely based on Russian statements during the last eighteen months as well as on the treaty draft issued on 29 November.

Stephen F. Cohen, "The New American Cold War," The Nation (21 June 2006).
} 
which was concluded in 1990 and envisioned the end of confrontation and divisions in Europe and the coming of an age of relations based on respect, cooperation, and equal security for all European countries. ${ }^{4}$ Twenty years after the fall of the Berlin Wall and the beginning of the dissolution of the Eastern Bloc, the question today is not so much about the necessity of a serious debate on security relations in Europe-because there is obviously a growing need for remedial maintenance - but rather about the causes of the current state of affairs and the potential of future dialogue.

A significant number of the current problems of the existing European security architecture result from Russia's deep dissatisfaction with security structures as they evolved from 1989-90 onwards. From a Russian perspective, the source of all its problems is the continuing existence of NATO and its seemingly inexorable process of eastward enlargement. As a part of the "Two Plus Four Agreement" of 1990, which paved the way for German reunification, the NATO member states and the Soviet Union came to an understanding that they would not station or deploy foreign armed forces and nuclear weapons or their carriers on East German soil. ${ }^{5}$ The desire to overcome the European bloc structure was distilled into a simple formula: the Soviet Army was pulling back from the territories of former Warsaw Pact countries, and the West would not (militarily) move in to take its place. Although this deal was never put down in writing (with the exception of the Two Plus Four Agreement), the verbal assurances of high-ranking NATO representatives followed its spirit. ${ }^{6}$ The three-stage enlargement of NATO that followed, however, incrementally put an end to this agreed security status quo, and deeply undermined Russian confidence in any assurances given by NATO.

Nevertheless, NATO's strategic outreach to the east was not one-sidedly assertive, especially at the beginning. Instead, its impact was cushioned by attempts to engage Russia in cooperation. Enlargement was made palatable to Russia, at least in NATO's view, by the holding of several summits between Washington and Moscow, the adaptation of the Treaty on Conventional Armed Forces in Europe (CFE), and the NATORussia Founding Act. At the same time, the enlargement of the Alliance was perceived by Moscow as a de facto roll-back of Russia's influence in Europe. For the Kremlin, triumphalism about the end of the Cold War in sections of the U.S. political elite cou-

4 Conference on Security and Cooperation in Europe, "Charter of Paris for a New Europe," (21 November 1990); available at http://www.ena.lu/charter-paris-new-europe-paris-21november-1990-020302522.html.

5 Art. 5, Para. 3 of the Treaty on the Final Settlement with Respect to Germany (12 September 1990); available at www.ena.lu/treaty-final-settlement-respect-germany-020102264.html.

6 Then NATO Secretary-General, Manfred Wörner stated in 1990 that "[ $t$ ] spond to the erosion of the Warsaw Pact with the weakening or even dissolution of the Atlantic Alliance; the only response is to establish a security framework that embraces both alliances: in other words one that draws the Soviet Union into a cooperative Europe. ... The very fact that we are ready not to deploy NATO troops beyond the territory of the Federal Republic gives the Soviet Union firm security guarantees." Manfred Wörner, "The Atlantic Alliance and European Security in the 1990s," address to the Bremer Tabaks Collegium, Brussels, 17 May 1990. 
pled with a perceived refusal on the part of the U.S. to enter into a dialogue with Russia as equals meant that the process of enlargement, which Moscow already viewed critically, was seen in a still more negative light. Moscow's perception that the Alliance's strategy was Janus-faced was highlighted every time Russia vociferously promoted an alteration of existing European security structures. Notwithstanding the "Billand-Boris-Show" put on by the U.S. President Bill Clinton and the Russian President Boris Yeltsin during the 1990s, and the signing of the NATO-Russia Founding Act, Moscow's desire for the Organization for Security and Cooperation in Europe (OSCE) to be upgraded to a full-fledged regional organization was rejected, especially by Washington. At the same time, the pace of NATO enlargement was being accelerated.

Although Russia had assumed that Russian-American relations would substantially improve in the aftermath of $9 / 11$ and therefore strongly aligned itself with the Bush Administration in the fight against terrorism, Washington answered with the termination of the Anti-Ballistic Missile Treaty (ABM) in 2002, the submission of the woolly Strategic Offensive Reduction Treaty (SORT), a hardening of the link between the socalled "Istanbul Commitments," and the ratification of the Adapted CFE Treaty by NATO members. At the same time, the Rome Declaration between NATO and Russia placed their mutual relations on an entirely new footing. It stated that NATO and Russia would work together "as equal partners in areas of common interest." That at least was the official wording. What followed in practice were U.S. efforts to station components of an anti-ballistic missile system in the Czech Republic and Poland, the stationing of U.S. rotation units at brigade strength in Bulgaria and Romania, the mantralike reiteration of the "Istanbul Commitments," the promise of eventual NATO accession to Ukraine and Georgia, and the recognition of Kosovo's independence in contradiction to international law.

In 2002, at the latest, Russia started to adopt a more aggressive stance toward NATO and some of its direct neighbors. It delayed the CFE process by incompletely withdrawing its troops and equipment from Moldova and Georgia; it made an obvious endeavor to establish the Collective Security Treaty Organization (CSTO) as a kind of counterweight to NATO; it continually attempted to intervene in Moldova's internal affairs, culminating in the Kozak Memorandum of $2003 ;^{8}$ and it enacted a unilateral and legally questionable suspension of the CFE. Vladimir Putin gave an inflammatory speech at the Munich Security Conference of 2007, which brought many of these issues back to the surface. In addition, there have been recurrent quarrels with Ukraine about the supply of Russian oil and gas, along with the Russian-Georgian war of 2008, which went hand-in-hand with Moscow's unilateral recognition of the independence of South Ossetia and Abkhazia in breach of international law. As an additional provocation to NATO, Medvedev threatened to station conventional Iskander short-range mis-

7 "NATO-Russia Relations: A New Quality," Declaration by Heads of State and Government of NATO Member States and the Russian Federation (Rome, 28 May 2002).

8 "Russian Draft Memorandum on the basic principles of the state structure of a united state in Moldova" (17 November 2003); available at http://www.pridnestrovie.net/kozak_ memorandum.html. 
siles in the oblast of Kaliningrad, and the latest amendment to the Russian Law on Defense allows for the extra-territorial deployment of Russian troops to protect Russian citizens abroad from armed attack. Furthermore, ideological differences further encumbered Russia's already difficult relations with NATO (and especially the United States), as Washington's sense of mission under the label of "democracy promotion" was opposed by Russia's self-prescribed model of "sovereign democracy."

When one reviews this chain of events in its entirety, it becomes less surprising that a proposal for a revision of Europe's security structures is now on the table. Nor should we be astonished that the initiative issued from Moscow, because little or nothing has changed in Russia's own perception of a security imbalance since the demise of the Soviet Union. In light of the developments detailed above, the last ten years really do seem to represent a lost decade for Euro-Atlantic security.

\section{From Berlin to Corfu: The Genesis of the Russian Proposals}

Less than a month after his inauguration as President of the Russian Federation, Dmitry Medvedev used his first official visit to Berlin as the opportunity to propose the "drafting and signing [of] a legally binding treaty on European security in which the organizations currently working in the Euro-Atlantic area could become parties." According to Medvedev, the current structures are pre-programmed for a restoration of bloc policy approaches. In order to overcome this divide, he proposed looking at a "regional pact based, naturally, on the principles of the UN Charter and clearly defining the role of force as a factor in relations within the Euro-Atlantic community. This pact could achieve a comprehensive resolution of the security indivisibility and arms control issues in Europe that are of such concern to us all." At the same time, he suggested "holding a general European summit to start the process of drafting this agreement." At its core, Medvedev's initiative aimed at: 1) universal and legally binding principles; 2) an end to NATO enlargement; 3) a solution to the arms control deadlock in Europe; and 4) a summit of all parties concerned.

Only four months later, overshadowed by the events of the Russian-Georgian war, Medvedev fleshed out his initiative during the World Policy Conference in Evian. Four "No's" were at the center of his call for equal security for all: "no ensuring one's own security at the expense of others. No allowing acts (by military alliances or coalitions) that undermine the unity of the common security space [...] no development of military alliances that would threaten the security of other parties to the Treaty $[\ldots]$ no state or international organization can have exclusive rights to maintaining peace and stability in Europe. $" 10 \mathrm{He}$ also argued that the treaty should reaffirm the principles of international law, especially with regard to the right to sovereignty, territorial integrity, and

9 Dmitry Medvedev, Speech at Meeting with German Political, Parliamentary, and Civic Leaders, Berlin, 5 June 2008; available at www.mid.ru/brp_4.nsf/0/c080dc2ff8d93629c32574600 03496c4?OpenDocument.

10 Dmitry Medvedev, Speech at the World Policy Conference, Evian, 8 October 2008; available at http://eng.kremlin.ru/speeches/2008/10/08/2159_type82912type82914_207457.shtml. 
political independence of all states, and the inadmissibility of the use of force or the threat of its use. In addition, Medvedev called for the codification of a new approach to conflict prevention and the peaceful settlement of conflicts in the Euro-Atlantic space. Finally, he stated his desire that new cooperation mechanisms should be explored in the realm of arms control and for combating WMD proliferation, terrorism, and drug trafficking. ${ }^{11}$ In his reply, the French President Nicolas Sarkozy received Medvedev's proposals favorably and suggested a review of all security-relevant structures on the continent. "Why not modernize together our thinking, reflexes, and habits that date back to the Cold War?" "2 he asked, recommending the OSCE as the most suitable forum, as it includes all actors of pan-European security as equals.

Since those two speeches by Medvedev, both governmental and non-governmental Russian representatives have used every opportunity to publicly reiterate Medvedev's proposals and to refer to their raison d'etre. ${ }^{13}$ In December 2008, the Finnish OSCE Chairmanship turned its attention to the Russian initiative during an informal working lunch at the Helsinki Ministerial Council meeting. Although reactions ranged from outright rejection to the proposal of an informal ministerial meeting during the first half of 2009, the Greek OSCE Chairmanship worked out a way to keep the discussion alive into 2009. ${ }^{14}$ At the OSCE's 2009 Annual Security Review Conference, the Russian Foreign Minister Sergey Lavrov gave substance to Medvedev's rather vague proposals for the first time. ${ }^{15}$ According to Lavrov, a future security treaty should be based on four primary "conceptual blocs." The first bloc should specify the relations between states in a legally binding manner. Lavrov therefore repeated the calls already made by Medvedev in Evian for common security based on the principles of equality and indivisibility. For the second bloc, intended to deal with the issues of arms control, confidence-building, and restraint and reasonable sufficiency in military doctrine, Lavrov demanded a clear definition of the term "substantial combat forces."16 The third thematic bloc was to be devoted to conflict resolution and to provide for procedures to

11 Medvedev, Speech at the World Policy Conference, Evian, 8 October 2008.

12 M. Nicolas Sarkozy, Speech at the World Policy Conference, Evian, 8 October 2008, available at http:/www.ambafrance-uk.org/President-Sarkozy-s-World-Policy.html.

13 Compare, for example, Sergey Lavrov's statement at the ministerial working lunch on the Russian initiative regarding a treaty on European security, OSCE MC.DEL/44/08 (Helsinki, 5 December 2008) with Fyodor Lukyanov, "Rethinking Security in "Greater Europe": Why Russia Is Seeking a New Architecture," Russia in Global Affairs 7:3 (July-September 2009), available in English at http://eng.globalaffairs.ru/numbers/28/1298.html. Dov Lynch, "The Corfu Process," in The Indivisibility of Security: Russia and Euro-Atlantic Security, ed. Andrew Monaghan (Rome: NATO Defense College, 2009), $35 \mathrm{ff}$.

15 Sergey Lavrov, Statement at the Opening Session of the OSCE Annual Security Review Conference, Vienna, 23 June 2009 (OSCE PC.DEL/480/09 English).

16 This term is related to NATO's commitment stemming from the NATO-Russia Founding Act of 1997 to not station any additional such troops on the territories of its member states. "Founding Act on Mutual Relations, Cooperation and Security between NATO and the Russian Federation" (Paris, 27 May 1997); available at www.nato.int/cps/en/natolive/official_ texts_25468.htm. 
prevent and peacefully resolve crises that were consistent with the principles of the Charter of the United Nations. The proposed focus of the fourth bloc was to be on cooperative arrangements to counter new threats and challenges. As justification for the proposals set forth, Lavrov referred to the Russian perception of a two-class society in the pan-European security space. While the principle of indivisible security was a political commitment for the OSCE's fifty-six member states, NATO offered its members legally binding assurance. In Lavrov's view, this will lead to an inevitable collision between the pan-European and bloc-based approaches, and to a fragmentation of the common European space.

The discussions within the OSCE finally led to what became known as the Corfu Process. After having acknowledged the need for ongoing discussion, the participants of the informal OSCE ministerial meeting held on the Greek island from 27 to 28 June 2009 channeled the loose dialogue into a regular series of ten rounds of discussions held in the Vienna Hofburg. The possible topics for discussion proposed by the Greek Chairmanship, led by Foreign Minister Dora Bakoyannis, included crisis management, conventional arms control, environmental security, energy security, as well as efforts to strengthen human rights, democracy, and the rule of law. ${ }^{17}$ Bakoyannis thus not only succeeded in keeping the debate within the only all-encompassing European security organization - the OSCE - but also extended it to the two remaining OSCE "baskets," which had been disregarded by Russia. According to the plan, the next step was supposed to happen at the OSCE Ministerial Council in Athens in early December 2009. The intention was initially to discuss a clarification of topics, the modalities of the forthcoming dialogue, and the near-term and long-term goals of the debate.

Apparently, the Russian leadership tried to frustrate this schedule. Most observers were surprised when the Kremlin issued a revised treaty document comprising fourteen articles on 29 November 2009, only three days before the start of the OSCE Ministerial Council meeting and four days before the upcoming meeting of foreign ministers of the NATO-Russia Council in Brussels.

\section{The Fourteen Articles: Possible Implications, Inconsistencies, and Shortcomings}

Medvedev's treaty draft can be divided into three parts. The first, comprising Articles 1 and 2, concentrates exclusively on the codification of universal "rules of the game." The second section sets forth mechanisms for conflict prevention and settlement. Starting with Article 9, the third part deals with technical aspects of the maintenance of the treaty.

Articles 1 and 2 correspond to existing norms. They oblige the parties to the treaty to observe the principles of "indivisible, equal, and undiminished security." To sustain these principles, no party to the treaty is to "undertake, participate in or support any

17 Greek Minister of Foreign Affairs Dora Bakoyannis, Opening Remarks to the Plenary Session of the Corfu Informal Meeting of OSCE Foreign Ministers on the Future of European Security, Corfu, 28 June 2009; available at www.osce.org/cio/item_1_38493.html. 
actions or activities affecting significantly [the] security of any other Party or Parties to the Treaty." This applies also to "military alliances, coalitions, or organizations" represented in the pan-European space. Furthermore, no party to the treaty shall allow the use of its territory or shall use "the territory of any other Party with the purpose of preparing or carrying out an armed attack against any other Party or Parties to the Treaty." Already, the woolly wording of those two articles leaves dangerous space for diverse interpretations. The phrase "actions or activities" (Art. 2, Para. 1) could apply to any action that one of the parties regards as affecting its security. The same could be said of the reference to the "decisions" of security alliances (Art. 2, Para. 2): these could include anything ranging from the admission of new members to collective obligations to adjust defense budgets, to name just two possible scenarios. If, for instance, NATO should want to admit another state to its Membership Action Plan, Russia could block this "decision" as inconsistent with Article 1. The same could apply to the inclusion of another state in the CSTO. As a consequence, and under the current geopolitical circumstances, Articles 1 and 2 would imply that the boundaries of alliances in Eurasia would be made permanent, at least provisionally. The result would be a security landscape dominated by two military alliances (NATO and the CSTO) alongside a number of unaffiliated states, inevitably condemned to neutrality. Even the phrase "armed attack" (Art. 2, Para. 3) is not adequately specified. In theory, it could also encompass attacks committed by non-state armed groups operating from uncontrolled territories of one state on the territories of another state (e.g. from Transnistria, Abkhazia, South Ossetia, Nagorno-Karabakh, etc.).

The second part of the document begins with Article 3. It includes six articles, and outlines specific mechanisms for conflict prevention and resolution. The actual sequence of the proposed consultation mechanisms (outlined in Article 4) is less interesting than the concept of voting and the rationale for convening a consultation. The draft treaty allows every party the right to request, through diplomatic means or by contacting the depositary, "information on any significant legislative, administrative or organizational measures" undertaken by a third party "which, in the opinion of the Requesting Party, might affect its security" (Art. 3, Para. 1). "Organizational measures" could here cover practically any domestic or foreign political event, such as, for example, the conclusion of an arms cooperation agreement between a party to the treaty and a state not included in the treaty. In the case of a violation or the threat of violation of the treaty (this includes every action inconsistent with Articles 1 and 2), the first step would be to hold consultations (discussed in Article 5). Following such consultations, a conference of the parties to the treaty may ensue, assuming that at least two parties to the treaty support such a request (Art. 6, Para. 2). The conference obtains legal force as soon as at least two thirds of the parties to the treaty take part in it. Decisions of the Conference "shall be taken by consensus and shall be binding" (Art. 6, Para. 3). Yet it is precisely this consensus procedure that would render decision-making impossible, for the simple reason that every party could use its veto power to prevent binding decisions from being reached. Moldova, for instance, could determine that the stationing of Russian troops in Transnistria amounted to a violation of the treaty without the host nation's consent. Moscow, in turn, could use its veto power to prevent any decision 
from being made by the conference convened as a result. In consequence, the conference would be nothing more than a venue for conversation.

Articles 7 and 8 deal with armed attacks (not defined) "or a threat of such attack against a Party to the Treaty." Besides including the obligation to assist the attacked state (Art. 7, Para. 2), Article 8 stipulates the procedures for the convening of an extraordinary conference in such a case. Decisions of this extraordinary conference also have to be made by common consent to obtain legal force. If the armed attack originates from a party to the treaty, the party loses its vote for the purposes of making a decision. This leaves a certain uncertainty regarding who ultimately decides whether an armed attack did take place and what its territorial origin was. As a consequence, it is not clear who decides whose vote will be withheld. In the real case of the RussianGeorgian war of 2008, for instance, the mechanisms of the treaty would therefore certainly not have prevented the conflict from quickly escalating.

Finally, in the third part of the draft treaty, Articles 9 through 14 deal with international rights and obligations of the parties, entry into force of the treaty, the accession of future members, and withdrawal from the treaty. Article 9, Paragraph 3 prohibits "international obligations incompatible with the Treaty." This means it is ultimately up to the discretion of every single party to the treaty to condemn unspecified "international obligations" of another party to the treaty as being "incompatible" with its own security arrangements. Hence, Russia could block a CFE inspection in Belarus with reference to Belarusian CSTO membership. The same would apply to any activity of the OSCE.

Medvedev's draft treaty includes all the extant security organizations in the panEuropean space - or that was at least what the Russian side announced. Article 10 therefore lists the EU, the OSCE, the CSTO, NATO, and the CIS as possible members. Unsurprisingly, the alliance of Georgia, Ukraine, Azerbaijan, and Moldova (GUAM), no particular favorite in Moscow, is not on the list of notified organizations or alliances. This contradicts the right of equal security for all as stated in Article 1.

In connection with a possible withdrawal, it is interesting to take note of the justification required. The document allows every party to withdraw from the obligations of the treaty "should it determine that extraordinary circumstances pertaining to the substance of the Treaty have endangered its supreme interests" (Article 14). What is meant by "extraordinary circumstances" and "supreme interests" is unclear. This is remarkable given the rhetorical vehemence with which Medvedev promoted his concept of a "legally binding" treaty "consolidat[ing] the Euro-Atlantic region as a whole" in the realm of "hard security." "18

All in all, Medvedev's draft treaty would secure Russia a number of vital geopolitical advantages. Foremost among these would be the legal codification of an end to NATO's eastward enlargement. It would also guarantee a Russian say in the Alliance's decision-making process, the permanent exclusion of certain post-Soviet states (e.g. Georgia and Ukraine) from NATO, the marginalization of GUAM, as well as an exclu-

18 Medvedev, Speech at the World Policy Conference, Evian, 8 December 2008. 
sive concentration on "hard" aspects of security, coupled with a neglect of the "soft" dimension of security (i.e., human rights, democracy, and the rule of law). The Russian proposal turns out to be particularly problematic where specific Russian interests collide with international law - e.g., in the prevention of further rounds of NATO enlargement. Whereas Medvedev's draft treaty explicitly allows for and respects the right of neutrality (Art. 9, Para. 4), its Article 2 effectively places strict limits on the rights of the parties to the treaty to freely choose their own security arrangements, e.g. through NATO accession. Article 2 therefore directly contradicts Article 1, which elevates "the principles of indivisible, equal and undiminished security" to treaty norms. Article 2 also stands in contrast to the OSCE's Charter for European Security of 1999, which grants every state the right "to be free to choose or change its security arrangements, including treaties of alliance, as they evolve." ${ }^{, 19}$ Nevertheless, Medvedev's draft explicitly refers to the Charter in its preamble. Such inconsistencies are either intended to support as yet uncertain political goals, or are the result of almost unbelievably sloppy work.

However, Medvedev's draft also provokes disappointment with regard to previously voiced Russian announcements about what the content of the treaty would be. Going against those prominent announcements, important fields of security are simply missing. To begin with, the draft leaves out entirely the topics of arms control and military sufficiency. Neither the moribund CFE regime nor the development of further confidence- and security-building measures such as the Vienna Document is mentioned. The same applies to the debate about "substantial combat forces." Moreover, the whole sphere of "soft" security, which constitutes the third "basket" of the OSCE, is blocked out, as is the urgent area of energy security. Contrary to several announcements made by Russian officials, Medvedev's draft does not offer new cooperation mechanisms to counter proliferation, terrorism, and illicit drug trafficking. Likewise, for one of the most pressing problems of pan-European security - the question of subregional conflicts - the document presents no innovative attempt at a solution. If anything, by using the imprecise expression "armed attack," the treaty could heighten the likelihood of conflict in areas such as Nagorno-Karabakh. In this connection, it is furthermore noticeable that Medvedev's fourteen articles forget to mention the stationing of foreign troops on the territory of another party to the treaty. Against the background of the CFE controversy about the presence of Russian troops in Moldova and Georgia, this oversight seems unsurprising. ${ }^{20}$ At the same time, the document binds parties to the treaty that are members of military alliances, coalitions, or organizations to respect principles set forth in the Charter for European Security and other documents adopted by the Organization for Security and Cooperation in Europe (Art. 2, Para. 2). Without any doubt, the 1994 Code of Conduct on Politico-Military Aspects of Security is an integral part of such OSCE documents. Article 14 of the Code of Conduct explicitly

19 Charter for European Security, Art. II, Para. 8 (Istanbul, 8 November 1999); available at www.osce.org/item/17497.html.

20 Ulrich Kühn, "From Capitol Hill to Istanbul: The Origins of the Current CFE Deadlock," CORE Working Paper 19 (December 2009). 
ensures that "a participating State may station its armed forces on the territory of another participating State in accordance with their freely negotiated agreement as well as in accordance with international law." 21

\section{The Russian Proposals of the Mid-1990s: Similarities and Differences}

Russian proposals for the modification of Europe's security structures are far from a new phenomenon. They are part of political tradition that can be traced back at least to the nineteenth century. ${ }^{22}$ The Kremlin is now in a much stronger position than it was when Russia attempted to change the existing European security architecture in the mid-1990s. While Boris Yeltsin at times appeared to behave like a petitioner, the Medvedev/Putin dual leadership can at least point to a more stable national economy and massive popular support. Though the renaissance of Russia's Great Power ambitions still rests on two rather fragile pillars - the world's largest nuclear arsenal and Siberia's seemingly endless supply of natural resources - the Kremlin has, since the turn of the millennium, not only undertaken a course of internal consolidation, but has also succeeded in restoring a component of external power projection toward its near neighborhood to its foreign policy portfolio. This new "strength" was made most bluntly manifest in the 2008 war with Georgia, which was accompanied by the tacit termination of NATO's eastward enlargement (at least for the time being).

The current Russian proposals inevitably evoke the feeling of déjà-vu. Russia already put forward proposals for the realignment of Europe's security structures in the mid-1990s. But while Moscow was then primarily aiming to transform the OSCE into a full-fledged regional security organization with a legally binding mandate, ${ }^{23}$ today's proposals aim at legally binding rules, this time in the form of a treaty. Moscow would still like to see a hierarchization of European security structures, and hence the subordination of NATO under the vague long-term rubric of equal security for all. The history of the Russian attempts, and Moscow's isolation, is well known. ${ }^{24}$ Yet a short review could turn out to be eye-opening in view of the similarities and differences across time.

After having vainly championed the upgrading of the OSCE to a regional collective security organization with legally binding character during the 1994 CSCE/OSCE Budapest Summit, which had foundered as a result of Washington's decision in favor of NATO enlargement, in September 1996 the Russian leadership took up the proposal of elaborating a "new security system" encompassing all international organizations ac-

21 OSCE, "Code of Conduct on Politico-Military Aspects of Security," 3 December 1994 (OSCE DOC.FSC/1/95); available at www.osce.org/item/4256.html.

22 Adam Daniel Rotfeld, "Does Europe Need a New Security Architecture?" Finnish Institute of International Affairs and MFA (March 2009): 2 et seq.

23 CSCE, DOC.433 (30 June 1994).

24 Victor-Yves Ghebali, "Growing Pains at the OSCE: The Rise and Fall of Russia's Pan-European Expectations,” Cambridge Review of International Affairs 18:3 (2005): 375-88. 
tive in the realm of European security. ${ }^{25}$ The Russian proposals and demands between 1994 and 1996 read like a blueprint of today's drafts. Then Deputy Minister of Foreign Affairs Nikolai Afanasjevski, for instance, claimed the indivisibility of security during the first meeting of the High Council of the OSCE in 1995. According to Afanasjevski, no state should ensure its own security at the expense of others. Furthermore, he called for mechanisms for the implementation of mandatory consultations, the elaboration and signing of a Euro-Atlantic or Eurasian cooperation treaty, and the adaptation of existing treaties on military aspects of security to take account of the changing realities of the European security landscape. ${ }^{26}$ This proposal also insisted, "no state, no group of states and no organization should claim any dominant responsibility for peace and stability in the OSCE area or establish spheres of influence." ${ }^{27}$ A further similarity also seems to exist in the inability of the Russian leadership, whether under Yeltsin or Medvedev, to express their point of view in concrete terms. Thus, in 1995, the Russian academic Andrei Zagorski criticized this inability as being distinctive of the project. ${ }^{28}$ According to Zagorski, introducing a concept of an all-encompassing security model seems to serve only the objective of keeping the topic of "OSCE as the central European institution" on the table. Even these days, one cannot fend off the impression that, for Moscow, the most important thing is to be involved in a dialogue with the U.S. on a nearly equal footing, and to garner the resulting good publicity - all in the name of seeing its status as a great power renewed.

In contrast to Medvedev's proposals, the Russian leadership under Yeltsin did pay significant attention to the remaining two "baskets" of the OSCE's principles. Whereas demands for the recognition of the all-encompassing character of European security, including economic, legal, and humanitarian aspects, are not entirely alien to the current rulers of Russia ${ }^{29}$ (at least at the level of rhetoric), they do not find concrete political expression in the recent draft treaty. This may on the one hand reflect Russia's now more than ambivalent stance toward the "human dimension" of the OSCE. On the other hand, it may be due to the primacy of a concentration on Russia's own economic consolidation. But however their livery has been changed, one can also detect here echoes of former Russian attempts to prevent NATO enlargement. During the mid-1990s, this goal was pursued by efforts to establish "round tables"” and mutual security guarantees given by Russia together with the Western European states to the countries of Central

25 Yevgeny Primakov, Speech to the OSCE Permanent Council, 20 September 1996 (OSCE REF.PC/587/96).

26 Quoted in Andrej Zagorski, "Rußland und die OSZE-Erwartungen und Enttäuschungen," in OSZE-Jahrbuch 1995, eds. IFSH (Baden-Baden: Nomos, 1995), 112.

27 Quoted from Heinrich Schneider, "The "European Security Model for the 21st Century - A Story without an Ending?" in OSCE Yearbook 1997, eds. IFSH (Baden-Baden: Nomos, 1997), 243.

Zagorski, "Rußland und die OSZE—Erwartungen und Enttäuschungen," 113.

29 Medvedev, Speech at the World Policy Conference, Evian, 8 December 2008. 
and Eastern Europe. ${ }^{30}$ In Europe's post-enlargement landscape, Articles 1 and 2 of Medvedev's draft treaty are now replacing such efforts.

The requirement for pragmatic cooperation that was triggered by the international financial crisis as well as Washington's willingness to push the "reset button" leads to a situation where, for the first time since the end of the Cold War, a Russian push to overhaul existing security structures could meet with some degree of acceptance. As in the mid-1990s, today's process could be a long-lasting one, especially in view of the complexity of the issues that need to be dealt with (and always assuming that the Kremlin will add its own dose of inertia to its own proposals). In contrast to its stance during the Yeltsin years, Moscow will now probably not settle for a merely politically binding document akin to the 1999 Charter for European Security. The Russian leadership seems too self-confident to do that. Should Medvedev's initiative follow the "normal" routine within the OSCE, this could lead to a Russian withdrawal from the debate. A look back fifteen years into the past should be enough to remind Moscow of the discrepancy between its aspirations to a sui generis capacity to shape European security policy and the geopolitical reality in Europe today.

\section{The Subsequent Debate}

As the first treaty draft only reached the OSCE member states on the eve of the Ministerial Council in Athens, the meeting was necessarily dominated by Moscow's surprising actions. Although the Greek Chairmanship had worked hard to try to embed Medvedev's initiative within the OSCE framework, Athens revealed that Moscow viewed the Corfu Process and its own proposals as two different, albeit overlapping, issues, and that it saw the OSCE as the wrong forum for a discussion. ${ }^{31}$ This apparently led to a serious dispute behind the scenes, as the result of which Moscow backed down and agreed upon a continuation of the Corfu Process. ${ }^{32}$ In concrete terms, the OSCE member states concluded that they would transfer the dialogue to Vienna, where they would hold regular discussions and present an interim report by the end of June 2010 "summarizing proposals put forward by the participating States within the Corfu Process. ${ }^{, 33}$ Further steps are to be concluded by the Permanent Council and the Forum for Security Cooperation.

30 In a secret letter dated 15 September 1993 to the heads of state and government of the U.S., Great Britain, France, and Germany, Boris Yeltsin wrote that Russia "would be prepared, together with NATO, to offer official security guarantees to the East European states with a focus on ensuring sovereignty, territorial integrity, inviolability of frontiers, and maintenance of peace in the region." Quoted from Rotfeld, "Does Europe Need a New Security Architecture?", 14.

31 Russian Minister for Foreign Affairs Sergey Lavrov, Statement at the Seventeenth Meeting of the OSCE Ministerial Council, 1 December 2009 (OSCE MC.DEL/19/09).

32 Reinhard Veser, "Moskau verliert gegen Korfu. Ein Dämpfer für Medwedjews Sicherheitsinitiative," Frankfurter Allgemeine Zeitung (3 December 2009): 5.

33 OSCE, "Furthering the Corfu Process," 2 December 2009 (OSCE MC.DEC/1/09). 
The dialogue is thus ironically proceeding within exactly that organization that Russia has increasingly been criticizing for its "double standards" in recent years. ${ }^{34}$ The rushed release of the draft treaty, the lack of coordination with the Greek Chairmanship, and (last but not least) the exclusive concentration on "hard" aspects of security can be seen as indicators that Russia refuses to accept the OSCE as the correct forum for dialogue. Moscow's stance is not unfounded. The lessons of the 1990s in particular taught Moscow that, within the OSCE, its own security proposals merely result in the issuing of tentative documents. There is therefore a risk that Moscow will lose interest in its own initiative. Contradicting this hypothesis, however, are recent Russian statements that see Medvedev's draft rather as a stimulus to a long and intensive debate. ${ }^{35}$ According to Lavrov, "the journey is only just beginning., 36

The Russian point of view could be bolstered by one momentous coincidence. Since the beginning of 2010, Russia's close ally Kazakhstan has held, for the first time, the OSCE Chairmanship. Kazakhstan's overarching aim, besides diverting attention from its own internal situation, is to culminate its chairmanship by holding an OSCE summit in its own country. ${ }^{37}$ To accomplish this goal, Astana would have to succeed in filling the summit with sufficient political substance. That is a goal that a more tangible version of a statement of principles regarding pan-European security would fulfill perfectly. One can therefore assume with some certainty that Kazakhstan will at least offer consistent support to the idea of a dialogue on the Russian proposals during 2010. Whether the Central Asian state is able to launch its own substantial initiatives remains to be seen.

The first reactions of NATO and the U.S. to Medvedev's proposals turned out to be unambiguously negative. On the occasion of his latest visit to Moscow, NATO Secretary-General Anders Fogh Rasmussen stated unequivocally, "I don't see a need for new treaties or new legally binding documents because we do have a framework already.",38 Following this line of argumentation, U.S. Secretary of State Hillary Clinton, in her speech before the French Military Academy on 29 January 2010, stressed the need to pursue the dialogue with Russia in the context of existing institutions such as the OSCE

34 Russian Minister for Foreign Affairs Sergey Lavrov, Statement at the Opening Session of the OSCE Annual Review Conference, Vienna, 23 June 2009 (OSCE PC.DEL/480/09).

35 Alexander Grushko, "Proposals from the Russian President Dmitry Medvedev on the New European Security Treaty: Origins and Prospects," RIA Novosti (15 December 2009).

36 Russian Minister for Foreign Affairs Sergey Lavrov, Statement at the Seventeenth Meeting of the OSCE Ministerial Council, 1 December 2009 (OSCE MC.DEL/19/09).

37 The last OSCE Summit to be held was in Istanbul in 1999. According to the Kazakh President Nursultan Nazarbayev, "The ten-year interval since the last OSCE summit is an illustration of the fact that the consensus base is in stagnation, if not in crisis. In this regard, we call upon the OSCE participating States to support Kazakhstan's initiative urging the convening of a summit in 2010." "Text of the video address by President Nursultan Nazarbayev on the occasion of Kazakhstan's assumption of the Chairmanship of the OSCE," 14 January 2010 (OSCE CIO.GAL/4/10).

38 Quoted in Conor Sweeney, "NATO Chief Opposes Russia's Security Pact Proposal," Reuters (17 December 2009); available at www.reuters.com/article/idUSTRE5BF38D20091217. 
and the NATO-Russia Council "rather than by negotiating new treaties." 39 At the same time, she acknowledged the necessity of substantive dialogue with Russia, the revitalization of existing European arms control regimes, and a strengthening of the OSCE's role.

The greatest risk for Medvedev's attempt lies without any doubt in the possibility that the West will adopt a passive "wait and see" attitude, or that it will express active disinterest. The modest reaction of the Western media is a serious warning signal. Negative reactions from Georgia and NATO Headquarters, among others, were to be expected. Yet such negative reactions should not discourage Western governments from dealing with Moscow's proposals thoroughly. Quite rightly, Wolfgang Ischinger, Chairman of the Munich Security Conference, pointed out the opportunities a restarted security dialogue with the Kremlin could create. ${ }^{40}$ Positive undertakings, such as the establishment of a Euro-Atlantic Security Initiative by the Carnegie Endowment with the participation of prominent political figures, also send important signals. However, the discussion should not become a purely academic debate.

\section{Feasibility vs. Opportunity: An Attempt at a Conclusion}

An assessment of the feasibility of Medvedev's proposals compared to the opportunity they represent turns out to be straightforward. In its current form, the Kremlin's draft treaty does not offer an increase in security. The draft lacks substance, exactitude, and political foresight. Demands that obviously aim to undermine NATO's collective security commitments will clearly be rejected by the Alliance. The same applies to any legal codification of the future status of sovereign and free nations on Russia's periphery. A complete phasing out of the "human dimension" must not happen, especially with the participation of the EU as a community of values. For the reasons presented here, the Russian draft treaty in its current form is not politically feasible, neither right now nor in the near future.

Twenty years after the fall of the Berlin Wall, however, the proposals blatantly reveal the extent to which the West has neglected Russia's security interests. In equal measure it has failed to understand Russia's perceptions of its increasing geopolitical isolation. The story of the 1990 s speaks volumes about this perception. As well as underlining the non-negotiability of the principles of human rights, democracy, and the rule of law, any future dialogue with the Kremlin also needs to face up to the legitimate criticism of double standards and has to find answers to such allegations. As an initial confidence-building measure, it is essential that the West change its attitude in dealing with Moscow. In this respect, the Obama Administration seems to be on the right path.

39 Hillary Rodham Clinton, "Remarks on the Future of European Security," L'Ecole Militaire, Paris (29 January 2010).

40 Wolfgang Ischinger, "Keine Angst vor Medwedew! Die russische Initiative zur europäischen Sicherheit ist beachtlich," Tagesspiegel (3 December 2009); available at www.tagesspiegel.de/meinung/kommentare/Russland-Nato;art141,2965593. 
Aside from the ongoing Corfu Process, the format of a future dialogue remains open to discussion. The OSCE Platform for Cooperative Security, ${ }^{41}$ which was established in 1999, is one possible instrument, as it already has an inclusive approach featuring the participation of all European security organizations. This would also be a way of raising the profile of this instrument, whose performance currently lags behind its ambitious aspirations. The possible topics of a prospective security debate could range from arms control, energy security, environmental security, and financial security, to unresolved territorial conflicts in Eurasia, terrorism, and drug-related crime, to WMD proliferation, the situations in Afghanistan and Pakistan, and the problem of radical Islamization in Central Asia. NATO could also regain trust by tackling one of Russia's most urgent concerns: the imbalance of conventional forces in Europe to the disadvantage of Russia. For this purpose, the deadlocked CFE Treaty would commend itself. A resumption of the treaty's verification regime by Russia, coupled with parallel concessions by NATO on the "flank" issue and the "Istanbul Commitments," could be an important precursor stage to the negotiation of a "CFE III." 42 In the long run, a step of this kind could be in the interest of the United States as well, as it would serve to bolster President Obama's vision of a "global zero."

One possible risk inherent in any future security dialogue is that it could be reduced entirely to bilateral consultations between Moscow and Washington. In the end, a dialogue of this kind between ostensible equal partners could again suffer from the United States' volatile Russia policy. In this context, the Republican Party's recent acquisition of the power to filibuster in the U.S. Senate could have a negative impact on future U.S. foreign policy, for instance with regard to the ratification of arms control treaties. Hence, the EU in particular faces a challenge to play a constructive role-and to remain internally consistent, if possible - in the upcoming discussions.

Dmitry Medvedev, together with the entire Russian leadership, has to accept criticism for endangering his own initiative by the hasty presentation of an insubstantial draft. The Kremlin's unexpected continued pursuit of this initiative could indeed indicate internal synchronization problems as well as conflicting interests within the administrative apparatus. At the same time, there can be no more contention over the fact that there is ample reason for improving existing structures in the long term. Whether Europe needs merely another organization or another document is doubtful. The OSCE in particular, with its associated instruments, already fulfills the structural preconditions for a comprehensive and collective pan-European security organization-except for the legal commitment. Moscow's insistence on legally binding regulations is naïve to the extent that a treaty can be no substitute for political solutions. To find possible solutions, it is necessary rather to intensify the debate by jointly identifying common ground as well as diverging perceptions. Although the quintessence of Medvedev's

41 "Operational Document: The Platform for Cooperative Security," in the Charter for European Security (Istanbul, 8 November 1999), 17-19; available at www.osce.org/item/ 17497.html.

42 Ulrich Kühn, "Conventional Arms Control in Europe: Overcoming the Impasse," Russia in Global Affairs (forthcoming, Summer 2010). 
THE QUARTERLY JOURNAL

proposals is a reiteration of familiar demands from the 1990s, they offer the opportunity for a serious dialogue. As the need for cooperative security measures increases, Europe should grasp this opportunity. 


\section{Bibliography}

Charter for European Security. Istanbul, 1999.

Charter of Paris for a New Europe. In Conference on Security and Cooperation in Europe., 1990.

Clinton, Hillary Rodham. Remarks on the Future of European Security. Paris: L'Ecole Militaire, 2010.

Code of Conduct on Politico-Military Aspects of Security. OSCE, 1994.

Cohen, Stephen F.. "The New American Cold War." The Nation (2006).

Euro-Atlantic Security. One Vision, Three Paths. EastWest Institute, 2009.

Founding Act on Mutual Relations, Cooperation and Security between NATO and the Russian Federation. Paris, 1997.

Ghebali, Victor-Yves. "Growing Pains at the OSCE: The Rise and Fall of Russia's PanEuropean Expectations." Cambridge Review of International Affairs 18, no. 3 (2005): 375-88.

Grushko, Alexander. "Proposals from the Russian President Dmitry Medvedev on the New European Security Treaty: Origins and Prospects." RIA Novosti (2009).

Ischinger, Wolfgang. "Keine Angst vor Medwedew! Die russische Initiative zur europäischen Sicherheit ist beachtlich." Tagesspiegel (2009).

Kühn, Ulrich. "Conventional Arms Control in Europe: Overcoming the Impasse." Russia in Global Affairs (2010).

Kühn, Ulrich. From Capitol Hill to Istanbul: The Origins of the Current CFE Deadlock In CORE Working Paper., 2009.

Lavrov, Sergey. Statement at the Opening Session of the OSCE Annual Security Review Conference, Vienna., 2009.

Lavrov, Sergey. Statement at the Opening Session of the OSCE Annual Review Conference. Vienna, 2009.

Lavrov, Sergey. Statement at the Seventeenth Meeting of the OSCE Ministerial Council., 2009.

Lukyanov, Fyodor. "Rethinking Security in "Greater Europe": Why Russia Is Seeking a New Architecture." Russia in Global Affairs 7, no. 3 (2009).

Lynch, Dov. "The Corfu Process." In The Indivisibility of Security: Russia and EuroAtlantic Security, 35 ff. Rome: NATO Defense College, 2009.

M. Sarkozy, Nicolas. Sarkozy, Speech at the World Policy Conference. Evian, 2008.

Medvedev, Dmitry. Medvedev, Speech at the World Policy Conference. Evian, 2008.

Medvedev, Dmitry. Speech at Meeting with German Political, Parliamentary, and Civic Leaders. Berlin, 2008. 
NATO-Russia Relations: A New Quality In Declaration by Heads of State and Government of NATO Member States and the Russian Federation. Rome, 2002.

Operational Document: The Platform for Cooperative Security In Charter for European Security. Istanbul, 1999.

Primakov, Yevgeny. Primakov, Speech to the OSCE Permanent Council., 1996.

Rotfeld, Adam Daniel. Does Europe Need a New Security Architecture?. Finnish Institute of International Affairs and MFA, 2009.

Russian Draft Memorandum on the basic principles of the state structure of a united state in Moldova., 2003.

Schneider, Heinrich. "The European Security Model for the 21st Century - A Story without an Ending?" In OSCE Yearbook 1997, 243. Baden-Baden: Nomos, 1997.

Sweeney, Conor. NATO Chief Opposes Russia's Security Pact Proposal. 17 December 2009 ed. Reuters, 2009.

Veser, Reinhard. "Moskau verliert gegen Korfu. Ein Dämpfer für Medwedjews Sicherheitsinitiative." Frankfurter Allgemeine Zeitung (2009): 5.

Wörner, Manfred. The Atlantic Alliance and European Security in the 1990s In address to the Bremer Tabaks Collegium. Brussels, 1990.

Zagorski, Andrej. "Rußland und die OSZE_Erwartungen und Enttäuschungen." In OSZE-Jahrbuch 1995, 112. Baden-Baden: Nomos, 1995. 